\title{
The Loss of Sovereignty: How International Debt Relief Mechanisms
}

\section{Undermine Economic Self-Determination}

\author{
Noel G. Villaroman \\ Monash University, Higher Degree by Research (HDR), Faculty of Law \\ Building 12, Law Building, Monash University \\ Clayton, Victoria 3800 Australia \\ Tel: 61-3-9792-9218; 61-403-094-432Ｅ-mail: Noel.Villaroman@law.monash.edu.au
}

\begin{abstract}
This article discusses the process that debtor countries go through in the two mechanisms created to work out solutions for their huge and unpayable external debts, namely, the Paris Club and the Heavily Indebted Poor Countries (HIPC) Initiative. As the international lending process is structured today, it is through these mechanisms that debtor countries obtain debt forgiveness, reduction or rescheduling. The absolute control of these two mechanisms by creditor countries will be examined, together with the crucial role reserved to the International Monetary Fund (IMF) as the final dispenser of the 'stamp of approval' whether debtor countries will ultimately get debt relief. Also, this article identifies the so-called 'conditionalities' that are attached to debt relief obtained through the Paris Club and HIPC Initiative. What sort of policy prescriptions, 'structural adjustments' or other domestic changes are being pushed through these mechanisms? And finally, this article examines how these conditionalities comport with the principle of economic self-determination of peoples that supposedly guarantees their right to pursue an independent process of economic development. Essentially, this article attempts to answer these questions: Are the Paris Club and HIPC mechanisms fundamentally at odds with economic self-determination? And more generally, are they respectful of the 'rule of law' in the international system?
\end{abstract}

Keywords: External debt, debt relief, conditionalities, economic self-determination, Paris Club, Heavily Indebted Poor Countries (HIPC) Initiative

The Loss of Sovereignty:

How International Debt Relief Mechanisms

Undermine Economic Self-Determination

By Noel G. Villaroman

\section{Introduction}

Budget constraints are severely undermining the capacity of governments of developing countries to provide their people even the most basic of social services. This lack of finance is in turn caused by several factors including, among others, huge military spending, pervasive corruption and large repayments of debts owed to the developed world. These factors, either singly or in combination, eat up government funds that can otherwise be spent on education, health, housing and other social services. Economists have a better way of describing it - these factors 'crowd out' essential public spending designed to benefit the people. (Note 1) As a result, these governments are unable to steer their countries towards the path of economic development and entire peoples are unable to enjoy the most fundamental of economic, social and cultural rights.

Among the factors that drain a developing country's financial coffers, one stands out for its sheer magnitude - the periodic repayments of external debts. During the period 2000-05, for example, 29 of the poorest countries of the world paid around US $\$ 15.3$ billion in servicing their combined external debts. (Note 2) This figure roughly translates to about US $\$ 210$ million of debt servicing every month. It represents the amount of wealth that was transferred from these poor countries to the developed world. More accurately, however, there is an actual human cost behind these seemingly innocuous figures - that is, real people and real lives adversely affected by huge debt servicing. They are the children who had to stop studying because their government imposed school fees they could not afford; the families who had to reside in makeshift shelters because their government could not provide affordable housing; infants who had to die because the government has no adequate program to address malnutrition and disease, and the list of human suffering goes on. 
The accumulation of external debts is like a pandemic that has seriously afflicted developing countries in many parts of the world. As a response, international mechanisms were created purportedly to provide a cure called 'debt relief'. The creation and operation of these mechanisms have been at the control of creditor countries who, like physicians bound by the Hippocratic Oath, take action based on their knowledge of the disease and feel that their professional duty compels them to treat it. Meanwhile, debtor countries have been relegated the role of ailing patients waiting in a long queue for their turn to be diagnosed and treated. The comparison, however, ends there and harsh reality sets in. The physicians turned out to be not so knowledgeable about this affliction; and the purported cure, akin to a major surgical operation, turned out to be so invasive and intrusive that the patient's entire activities are placed under a strict regimen of do's and dont's.

There seems to be a clear-cut division of labour among three international mechanisms created to work out solutions for developing countries' unpayable external debts: (1) the Bank Advisory Committee, also referred to as the London Club, (2) the Heavily Indebted Poor Countries Initiative, and (3) the Paris Club of creditor countries. Private external debts are dealt with in the London Club process, while public external debts are worked out in the HIPC Initiative (for low-income developing countries meeting predetermined threshholds) and in the Paris Club (for middle-income countries and low-income countries that do not meet the HIPC threshholds). The London Club is an ad hoc grouping of private commercial banks that aims to resolve impending defaults of debtor countries in repaying their 'private external debts' (Sturzenegger and Zettelmeyer, 2004, pp. 12-19). This article only examines, and confines itself to, the Paris Club process and HIPC Initiative - the two mechanisms presently dealing with external debts owed to public creditors (e.g. bilateral creditors and international financial institutions).

The objective of this article is three-fold. First, this article discusses the process that debtor countries go through in the Paris Club and HIPC Initiative in order to obtain debt relief. The term 'debt relief' broadly encompasses any kind of modification in a country's debt obligations for the purpose of avoiding or getting out of a default situation, including debt forgiveness, reduction and rescheduling (Rieffel, 2003, p. 20). The absolute control of these two mechanisms by creditor countries will be examined, together with the crucial role reserved to the International Monetary Fund (IMF) as the final dispenser of the 'stamp of approval' whether debtor countries will get debt relief. Second, this article identifies the so-called 'conditionalities' that are attached to debt relief obtained through both the Paris Club and the HIPC Initiative. What sort of policy prescriptions, 'structural adjustments' or other domestic changes are being pushed through these mechanisms? And finally, this article examines how these conditionalities comport with the principle of economic self-determination of peoples that supposedly guarantees their right to pursue an independent process of economic development. Essentially, this article attempts to answer these questions: Are the Paris Club and HIPC mechanisms fundamentally at odds with economic self-determination? And more generally, are they respectful of the 'rule of law' in the international system?

\section{Debt relief through the Paris Club of creditor countries}

\subsection{Background}

The Paris Club is an informal grouping of creditor countries that functions as a venue for resolving requests for renegotiations made by debtor countries that have defaulted or at the brink of defaulting on their official bilateral debts (Toussaint, 1998, pp.287-88). The Club was never formally formed by a treaty or an international agreement. Instead, it emerged from the decades-long practice of creditor countries of convening in an ad hoc manner to decide on requests for restructuring from a particular debtor country (Korner, et al, 1986, p. 66). The Club had an open membership until the early 1990s when official documents began referring to the 'nineteen permanent members' comprised of Austria, Australia, Belgium, Canada, Denmark, Finland, France, Germany, Ireland, Italy, Japan, the Netherlands, Norway, Russia, Spain, Sweden, Switzerland, United Kingdom and the United States. (Note 3) Since the start of its operations in 1956, the Paris Club has concluded 408 agreements concerning 86 debtor countries; and the total amount of official bilateral debts covered in these agreements has been US\$513 billion. (Note 4)

Since 1956, creditor countries have collectively negotiated with debtor countries on a case-by-case basis that often resulted in the restructuring of loans for each requesting debtor country. The practice continued into the $1970 \mathrm{~s}$ that much of the procedures of the renegotiation became routine that led to their eventual codification. In the 1980s, debt restructurings in the Paris Club substantially increased such that the process 'evolved to become part of the machinery of the international financial system, although it remained largely ad hoc' (Rieffel, 2003, p. 56) In the 1990s, the Paris Club varied its treatment of two groups of debtor countries. For the forty or so heavily indebted poor countries (all low-income countries), the thrust was towards a reduction of public external debts; while for middle-income countries the Club leaned towards debt rescheduling only without reducing their total debt (Rieffel, 2003, p. 56). This policy was changed in May 2003 when the finance ministers of the Group of Eight (G-8) countries, which are also the creditors with the largest debt exposure to developing countries, introduced 'a new Paris Club approach to debt restructuring' that includes the option of reducing the public external debts of middle-income countries (Rieffel, 2003, p. 56). Today, the Paris Club process is the only international mechanism available to debtor countries that need a reduction in their 
external debt but are ineligible to participate in the Heavily Indebted Poor Countries (HIPC) Initiative whose stringent criteria for eligibility prevent many debt-distressed countries from receiving debt relief.

\subsection{The IMF involvement in the Paris Club process}

The IMF is at the centre of the Paris Club process and plays a pivotal role in it from beginning to end. The Paris Club openly admits the fact of IMF-imposed conditionality as an absolute requirement for debt relief under the Club's operations. It argues that debt relief must be tied to a debtor country's compliance with IMF's programs because 'the economic policy reforms are intended to restore a sound macroeconomic framework that will lower the probability of future financial difficulties.' (Note 5)

How pivotal is the role of the IMF in the Paris Club process? First, a debtor country cannot submit a request for renegotiation without an agreement with the IMF on how to restore its debt repayment capacity. Without this agreement with the IMF, a debtor country's request for Paris Club renegotiation is doomed to fail right at the beginning (Seiber, 1982, pp. 66-67). Second, during the negotiation proper, the IMF's analysis and projections about a debtor country's economic and financial condition are made the basis of specific restructuring terms (Rieffel, 2003, pp. 77-78). Also, the repayment burdens that a debtor country can be expected to bear in succeeding years are determined by using IMF analysis (Korner, et al, 1986, p.67). Absent a favourable endorsement from the IMF that a debtor country has sound economic fundamentals to restore its debt repayment capacity, no debt rescheduling nor reduction can come out of the Paris Club. And finally, a successful Paris Club renegotiation usually results in a restructuring agreement that will run for two or more years. (Note 6) In this multi-year agreement, the debt relief to be granted in the second and succeeding years is dependent on whether the debtor country is 'in good standing with the IMF' after it has reviewed the country's compliance with IMF prescriptions during the previous year (Rieffel, 2003, p. 89). These examples of IMF's endorsement before, during and after the renegotiations is the application of the 'principle of conditionality' that the Paris Club religiously follows in all its renegotiations with individual debtor countries. The principle of conditionality states that (Note 7):

The Paris Club only negotiates debt restructurings with debtor countries that:

- need debt relief. Debtor countries are expected to provide a precise description of their economic and financial situation, - have implemented and are committed to implementing reforms to restore their economic and financial situation, and

- have a demonstrated track record of implementing reforms under an IMF program.

This means in practice that the country must have a current program supported by an appropriate arrangement with the IMF (Stand-By, Extended Fund Facility, Poverty Reduction and Growth Facility, Policy Support Instrument). The level of debt treatment is based on the financing gap identified in the IMF program.

In the context of external debts, 'conditionality' is the term used to refer to macroeconomic targets, policy and institutional changes, and other reforms that a developing country must reach or implement in order to receive or continue to receive debt relief (Buira, 2003, p. 58). In effect, the IMF performs a 'signalling role' for Paris Club creditor countries certifying that a debtor country is indeed implementing a plan to get out of its repayment difficulty (Helleiner, 2000, pp. 90-91). The IMF also performs a 'monitoring role' that ensures that the debtor country remains 'on track' with this plan, or otherwise the creditor countries will discontinue the debt relief. Therefore, in a very real sense, a debtor country's access to the Paris Club renegotiation process is dependent on whether the IMF acting like a gate-keeper gives its 'seal of approval'. Also, the grant and continuation of debt relief are both dependent on whether or not the IMF overturns its initial assessment about the debtor country.

\section{Debt relief through the Heavily Indebted Poor Countries (HIPC) Initiative}

\subsection{Criteria for eligibility}

The HIPC Initiative is an international mechanism established and managed by the IMF and the World Bank to assist eligible low-income countries experiencing an unsustainable level of public external debts owed to external creditors. Launched in 1996, and enhanced in 1999, the Initiative aims to provide debt relief to debtor countries that meet certain eligibility criteria. According to the IMF, the paramount objective is 'to reduce to sustainable levels the external debt burdens of the most heavily indebted poor countries' and to 'ensur[e] that no poor country faces a debt burden it cannot manage'. (Note 8)

The HIPC Initiative does not cater to all developing country debtors, instead it only accommodates those that are the poorest and the most indebted based on certain eligibility criteria. The poorest countries are those eligible for highly concessional lending from the International Development Association (IDA) (Note 9) and from the IMF's Poverty Reduction and Growth Facility; while the most indebted are those that face an 'unsustainable' debt situation. (Note 10) For a country's debt to be unsustainable, it must have a fixed ratio of $150 \%$ for a country's debt-to-export levels or, if a country has an unusually high level of exports, a fixed ratio of $250 \%$ for a country's debt-to-government revenues. (Note 11) External debts covered by the HIPC Initiative are those owed to the IMF and the World Bank, bilateral and 
multilateral creditors, and a limited number of private commercial creditors. According to the World Bank's figures, around 94 percent of the debts to be written off through the HIPC Initiative are owed to public external creditors, while only 6 percent are owed to private creditors. (Note 12)

\subsection{Stages of the HIPC and the Vehicles of IMF Conditionalities}

In order to obtain debt relief, a debtor country needs to successfully pass through three stages: pre-decision, decision and completion points. 'Pre-decision point' is the stage where the IMF and the World Bank assess whether a debtor country meets the level of poverty and indebtedness criteria and is therefore eligible (IMF and World Bank, 2001, pp. 2-5). In order to reach the next stage of 'decision point', a country should (i) have a record of macroeconomic stability as demonstrated by its staying 'on track' with implementation of an IMF program for three years, (ii) have prepared an interim Poverty Reduction Strategy Paper (interim PRSP), and (iii) have paid any outstanding arrears to preferred creditors. (Note 13) A PRSP is an economic plan of action that contains the policy and institutional reforms the IMF wants to see implemented in a debtor country over a period of time. It is purportedly 'country-owned' and prepared by the HIPCs themselves after a broad participatory process. (Note 14)

At decision point, a list of 'trigger conditions' that a country must comply to complete the HIPC process is formulated. At this stage, the IMF and the World Bank conduct a 'debt sustainability analysis' by examining every covered loan in order to ascertain a country's level of indebtedness and the debt relief it may receive. Debtor countries start receiving debt relief on a provisional basis during this stage. (Note 15)

For a debtor country to reach 'completion point', it is required to (i) carry out key structural and social reforms as agreed upon at the decision point (the floating trigger conditions), and (ii) implement a full PRSP satisfactorily for one year. At completion point, a debtor country receives the full amount of debt relief that then becomes irrevocable. (Note 16) The interim period between a country's decision and completion points varies in duration, and is contingent on how fast it can implement the trigger conditions formulated during the decision point.

From the above discussion, it can be summarised that there are two sets of conditionalities in the HIPC Initiative: one set is imposed in order to enter the HIPC process (i.e. reach decision point) and another one in order to complete it (i.e. reach completion point). A conditionality may either be: (i) expressly mentioned as a direct 'floating trigger condition' which, if all other trigger conditions are present, completes the HIPC process, or (ii) included in an interim PRSP or full PRSP of a debtor country. This ingenious scheme ensures that IMF conditionalities are present throughout the entire period that a debtor country prepares to enter the HIPC process, undergoes through it, and completes it. In many HIPC cases, it all adds up to more than a decade of waiting for debt relief while being under IMF conditionalities.

\subsection{Debt relief after 'completion point'}

Compared with the Paris Club process that results in either debt rescheduling or debt reduction, the HIPC Initiative only results in debt reduction for countries that complete it. Depending on the level of indebtedness that is 'sustainable' for a country as assessed by the IMF, the debt reduction may or may not be significant relative to a country's total external debt. A decade after its creation, the HIPC Initiative was supplemented by the Multilateral Debt Relief Initiative (MDRI) in 2006. The MDRI is an additional debt relief mechanism for debtor countries that have reached the completion point of the HIPC Initiative process. The MDRI allows for 100 percent debt relief (in other words, total debt cancellation) on 'eligible debts' only owed to four multilateral institutions: the IMF, the IDA of the World Bank, the African Development Fund (AfDF), and the Inter-American Development Bank (IADB). (Note 17) Eligible debts are those that were borrowed before end of December 2004 from the IMF, the AfDF and the IADB, and those borrowed before end of December 2003 from the IDA. (Note 18)

As of March 2009, forty-one countries participate in the HIPC Initiative at various stages as shown in Table 1 at the end of this article. According to the World Bank's computation, the HIPC Initiative and the MDRI have thus far provided the participating debtor countries a total debt relief of US $\$ 102.6$ billion at end-2008 net present value (NPV) terms. (Note 19) This accounts to about an 80 percent reduction of the debt stock of the 35 post-decision point countries.

\section{The Legal Compatibility between the Principle of Economic Self-Determination and the Conditionalities Imposed through International Debt Relief Mechanisms}

\subsection{Actual examples of conditionalities}

The conditionalities that must be met in the Paris Club and the HIPC Initiative may be classified according to their nature as 'quantitative' or 'structural'. The former are quantitative targets for macroeconomic variables including but not limited to the fiscal deficit, expansion of domestic credits, and accumulation of international reserves. On the other hand, structural conditionalities are changes in policy processes, legislation and institutional reforms. The IMF has traditionally employed the former in its lending programs but, beginning in the late $1980 \mathrm{~s}$, it has combined the two types of conditionalities (Buira, 2003, p. 57). Moreover, conditionalities may also be classified based on when they should be met by debtor countries. 'Prior actions' are conditionalities that a country needs to satisfy before the start of a 
lending program or debt relief; while 'performance criteria' are those that have to be met to ensure the release of credit tranches or continued debt relief (Woods, 2006, p. 70). According to the IMF, conditionalities in the Paris Club and HIPC Initiative are essential for two reasons: first, they provide assurances to debtor countries that as long as they satisfy these conditionalities the resources of the IMF are available to them; (Note 20) and second, the aim of the conditionalities is to improve the macroeconomic condition of a country so that it can remedy its debt repayment problems and to ensure that they do not happen again in the future. (Note 21)

Previous studies have analysed the typical conditionalities that are included in a country's arrangement with the IMF (in the case of the Paris Club) and the interim and full PRSPs (in the case of the HIPC Initiative). (Note 22) Relying on this secondary literature, Table 2 at the end of this article classifies these conditionalities into several categories. Whether these conditionalities are ultimately beneficial or harmful to debtor countries' economies is beyond the scope of this article. For sure, there are those who share the IMF's view that conditionalities are designed to improve a debtor country's macroeconomic fundamentals, in general, and restore its debt repayments capacity, in particular. Nicholas Hopkinson, for example, argue that without conditionalities the economies of debtor countries 'will not be able to grow ... and debt will not be recovered' (Hopkinson, 1989, p. 13) On the other side of the debate are those who argue that IMF conditionalities have in fact contributed to increasing poverty and marginalisation of the poor sectors of society. Several authors have reached this bleak conclusion about the long-term effects of conditionalities. (Note 23) This article will not substantially dwell on this raging debate. Instead, it will focus on the legal compatibility between the principle of economic self-determination and the conditionalities imposed upon debtor states through the Paris Club and the HIPC Initiative.

\subsection{Generalisations about debt relief conditionalities}

There are a number of crucial observations that can be made about conditionalities included in the Paris Club process and the HIPC Initiative:

First, with respect to an IMF program, the number of conditionalities has significantly increased in the 1980s and 1990s, resulting in the IMF's dominant influence in the debtor countries' economic and political systems (Buira, 2003, p. 61). For example, during the Asian financial crisis, South Korea had to satisfy 94 structural conditions; Thailand 73 conditions; and Indonesia 140 structural policy undertakings. (Note 24) On average, however, Graham Bird computes that the number of conditions contained in each IMF arrangement increased to 9.9 in 1993, 10.5 in 1994, 11 in 1995, 13 in 1996, and 16 in 1997 (Bird, 2001, pp.29-49). This diminishes the debtor countries' governmental domain where they exercise absolute and undivided authority. In the same vein, implementing a meticulous PRSP has resulted in a shrinking policy space for governments that leaves them with little or no option for midway policy manuevers or adjustments if the need arises. The net effect is a development process whose direction and management are shared by national authorities with external actors at best, or are considerably surrendered by the former to the latter at worst.

Second, conditionalities attached to the debt relief mechanisms have acquired a broad range of subjects that adversely affect the quality and implementability of IMF prescriptions to debtor countries. It must be noted that the IMF's expertise and original mandate only pertain to monetary, fiscal and exchange rate issues (Vreeland, 2007, pp. 5-37). However, conditionalities on debt relief have increasingly included 'structural' reforms over which the IMF has no or limited expertise (Buira, 2003, p. 61). Prescriptions to reform the civil service and changes to land ownership rights of aliens, just to name a few, are undoubtedly outside the core competence of the IMF yet such conditions found their way into decision point documents, PRSPs or other instruments through which conditionalities are inserted. The term 'mission creep' is used to refer to 'the systematic shifting of organizational activities away from original mandates' (Babb and Buira, 2005, p. 59). As will be shown later, an expanded area over which the Fund operates enables it to encroach further into the debtor state's economic and social policies.

Lastly, it has also been observed that certain conditionalities are required of debtor countries regardless of their social and economic circumstances. (Note 25) For example, those pertaining to privatisation and liberalisation have become too pervasive to the point of being mechanical in their application. This wholesale 'one-size-fits-all' formula of applying conditionalities smacks of propagating a particular economic ideology at the expense of an entire people's freedom to formulate their own national economic plans for themselves.

\subsection{Economic self-determination as the legal basis of the 'people's right to pursue an independent process of economic development'}

Article 1.2 of the United Nations (UN) Charter provides that one of the organisation's purposes is the development of friendly relations among states based upon the 'principle of equal rights and self-determination of peoples'. That the right to self-determination is recognised in the UN Charter itself, which some regard as the constitutional document of present-day international system (Simma, 2002, pp. 13-33), shows the right's high standing in the hierarchy of international law norms. The International Court of Justice (ICJ), in fact, characterised the right to self-determination in the Barcelona Traction Case as a "norm of the nature of jus cogens, derogation from which is not permissible under any circumstances' (ICJ reports, 1970, para. 72). According to Malcolm N. Shaw, the provisions of the UN Charter that deal 
with the right to self-determination are further elaborated in an 'authoritative' manner by the 1970 Declaration on Principles of International Law Concerning Friendly Relations (Shaw, 2008, p. 253). The Declaration states, among others, that 'all peoples have the right freely to determine, without external interference, their political status and to pursue their economic, social and cultural development, and every state has the duty to respect this right.' (Friendly Relations Declaration, UN General Assembly Resolution 2625 (XXV), 1970).

Aside from the UN Charter, other major treaties recognise the existence of the right of self-determination. Common Article 1(1) of the International Covenant on Economic, Social and Cultural Rights (ICESCR) and the International Covenant on Civil and Political Rights (ICCPR) provides that:

All peoples have the right of self-determination. By virtue of that right they freely determine their political status and freely pursue their economic, social and cultural development.

It is clear therefore that the right to self-determination has two incidences: a people can choose whatever type of government they wish and they can freely undertake their economic, social and cultural development. It is the right's 'economic aspect' that is highlighted in this article - that which guarantees a people's right to pursue a process of economic development which is free from unwanted intrusion or interference from outside actors. The self-determination of peoples necessarily entails an independent control of a country's economy in general and an effective involvement in economic planning in particular. Without these, self-determination is never complete. This is only logical because, for a people who have liberated themselves from a colonial, occupying or racist state and have declared political independence, their newly found freedom will be meaningless if this is not coupled with the freedom to choose an economic system that is viable for the country and the freedom to determine their own model of economic development. This is not to say, however, that the right to self-determination is applicable only for peoples escaping the clutches of colonialism, occupation or racism. Antonio Cassese, for example, argues that present-day international law limits the application of the right to self-determination to three situations: '(1) an anti-colonial postulate; (2) a criterion for condemning those forms of oppression of a people involving the "occupation" of territory; (3) an anti-racist postulate' (Cassesse, 1986, p. 135). However, the right's inclusion in the ICESCR and ICCPR ensures its continuing applicability well beyond the context of colonialism, occupation or racism. James Crawford observes that the right's inclusion in the two covenants has a 'tone of universality' (Crawford, 1988, p. 58). Consistent with this view, the International Law Commission expressed its opinion that the right to self-determination is of 'universal' application (ILC, 1988, vol. II, Part II, p. 64). In the two articles of the UN Charter where the right is mentioned (i.e. Articles 1(2) and 55), the contexts are different from issues of colonialism, occupation or racism which suggests the right's applicability in other situations (Crawford, 1988, p. 58). Therefore, the people of a state that is not colonialist, occupying nor racist also have the inherent freedom to choose their economic system and to determine their own model of economic development. Self-determination, including its economic dimension, is a continuing right of a people that does not end with their political emancipation. Even after political emancipation, the right continuously guarantees that a people can genuinely manage or lead their economic future.

Mohammed Bedjaoui equates the concept of economic self-determination with the 'right to development' when he stated that (Bedjaoui, 1991, p. 1184):

The 'right to development' flows from this right to self-determination and has the same nature. There is little sense in recognizing self-determination as a superior and inviolable principle if one does not recognize at the same time a 'right to development' for the peoples that have achieved self-determination. This right to development can only be an 'inherent' and 'built-in' right forming an inseparable part of the right to self-determination. (Emphasis original)

One obvious violation of the right to economic self-determination is 'economic coercion'. S. Azadon Tiewul describes 'economic coercion' as 'an attempt to constrain state conduct through the use of withholding of economic resources' (Tiewul, 1975, p. 670). Clearly, economic coercion can take on many forms and degrees ranging from discreet impositions in an onerous trade agreement to outright trade embargoes. The term 'economic coercion' does not include economic sanctions that may be lawfully imposed by the Security Council under the UN Charter. What the term encompasses are interventions in the internal and external affairs of another state using economic measures. This makes 'economic coercion' violative of another fundamental principle of international law - the principle of non-intervention (Dicke, 1988, p. 190). Citing several declarations of the UN General Assembly, Professor Oscar Schachter argues that 'economic coercion directed against the sovereign rights and independence of any state has been declared to be in violation of international law' (Schachter, 1976, p. 14) In the context of external debt, are the conditionalities being pushed through international debt relief mechanisms tantamount to 'economic coercion' upon debtor countries? Later sections of this article will attempt to answer this question.

\subsection{Debt relief conditionalities infringe a 'people's right to pursue an independent process of economic development'}

As previously discussed, the Paris Club and the HIPC Initiative both make debt relief conditional on whether a debtor country satisfies IMF conditionalities. In the way these international mechanisms are set up, all roads towards all forms of debt relief must pass through IMF conditionalities. If arranged along a spectrum, IMF conditionalities are between 
two extremes: on one hand, there are conditionalities that debtor states will satisfy on their own volition; on the other hand, there are conditionalities that are being complied with only because of pressure being exerted by the Fund. Tony Killick classifies conditionalities into 'pro forma' and 'hard core' conditionalities. The former are those that a debtor country and the IMF will readily agree to because they involve little concessions from the debtor, while the latter are those that are made only at the strong insistence of the Fund 'that would not otherwise be undertaken' because of their overreaching economic, political and social repercussions on domestic conditions. He concludes that hard core conditionalities are 'essentially coercive' and goes on to compare these with economic sanctions (Killick, 1995, pp. 603-16). In the significant majority of cases, the IMF conditionalities that are being pushed through the Paris Club and HIPC mechanisms are of the latter type.

However, some authors dismiss the idea of 'hard core' conditionalities. John W. Head, for example, opines that (Head, 2005, p. 75):

[S]tates are under no legal obligation to accept the conditions of an IMF loan, for the simple reason that states are under no legal obligation to seek an IMF loan in the first place - or, for that matter, to join the IMF. ... it is also true that if a government is dead-set against adopting the economic and financial policies prescribed by the IMF, that government can reject them by rejecting IMF involvement.

The flaw in this argument lies in its over simplicity. It refuses to acknowledge that the world of international finance in general, and the field of sovereign borrowings in particular, are so heavily influenced by the IMF. Can debtor states seeking debt relief realistically survive the aftermath if they refuse to be under IMF conditionalities? The 'signalling role' that the IMF plays is very critical to a debtor country's ability to attract future capital. Without a favourable signal from the IMF, it is highly unlikely that future credits or investments will pour into the country. This is due to the high regard that public and private sources of capital place on the IMF's seal of approval. An existing arrangement or program with the IMF is often regarded as evidence that a debtor country has sound economic policies and it has genuine intentions to improve its future ability to pay (Woods, 2006, p. 70). With its future economic survival at stake, a debtor country is simply without an effective alternative but to swallow the bitter pill of IMF conditionalities. In a very real sense, therefore, debtor countries are pressured to be under conditionalities because this is the only way in the international financial system, as it is structured today, to restore creditworthiness and regain access to a lifeline of external finance (Korner, et al, 1986, pp. 53-54).

The IMF is an international organisation with its own legal personality separate and distinct from its member-states. It is an undeniable fact, however, that decision-making within the IMF is heavily skewed in favour of the most developed countries which are, not surprisingly, also the major creditor countries. Seventy-one percent $(71 \%)$ of the total voting shares in the IMF is controlled by 13 major creditor countries, while only $29 \%$ is reserved to the developing countries (Rustomjee, 2005, pp. 10-11). These major creditor countries control the IMF through their voting shares in the Executive Board. Because voting shares are based on economic size, economically powerful countries 'can pressure the Fund to do their bidding' and sometimes use the IMF to advance political goals (Vreeland, 2007, p. 2). According to Lex Rieffel, it is a mistake to regard the IMF as an independent actor; it is in fact an 'instrument' of the major creditor countries (Rieffel, 2003, pp. 28-29). The nineteen permanent members of the Paris Club include the 13 creditor countries that control the IMF, (Note 26) while the HIPC Initiative is also being run by the IMF. The interlocking leadership structures of these debt relief mechanisms and the IMF is too glaring a fact to be overlooked, such that 'piercing the veil' of their supposed separate juridical existence is warranted pro hac vice - that is, at least in the limited context of external debt renegotiations.

How can externally-formulated conditionalities attached to debt relief be reconciled with a people's right to determine their own national economic policies? Or more to the point - when the Paris Club and HIPC Initiative exert financial and/or economic pressure upon a debtor state, do they infringe the latter's right to an independent development process?

Some argue that there is no pressure or coercion at all because debtor countries actually gave their consent to be under conditionalities when they voluntarily enter into an IMF program and freely participate in the Paris Club and HIPC Initiative. Karl M. Meessen insists that, in the case of conditionalities, '[e]ach word of consent expressed by debtor states... has to be taken at its face-value' (Meesen, 1986, p. 122). This argument is specious. Actual consent must not be mistaken with real, effective and freely-given consent. The dire consequences that await a debtor country by rejecting IMF conditionalities or by repudiating its debts are strong vitiating factors that render its ostensible consent problematic at best and coerced at worst. The gross inequality between affluent creditors and a desperate debtor distorts the very essence of 'freedom of contracts' and creates undue pressure that vitiates consent. While a 'problematic' consent may not be sufficient to legally invalidate an agreement with the IMF or participation in the Paris Club and HIPC Initiative, (Note 27) it does have an adverse implication upon a debtor country's right to an independent development process.

Some creditor countries view debt relief conditionalities as a form of benevolent policy advice in order to guide debtor countries to avoid a default situation. For example, the Australian government's official stance is to make debt relief to low-income countries conditional on the pursuit of 'good policies'. It regards debt relief conditionalities as a 'clear 
incentive for countries' to pursue 'sound economic and social policies'. (Note 28) However, the conditionalities that the Paris Club and HIPC Initiative require are not mere 'incentives'. An incentive connotes the idea of volition; it is an enticement that may or may not be taken. (Note 29) A policy action that ought to be done, lest adverse consequences follow, is more like the Sword of Damocles hanging over one's head. This thesis submits that the Paris Club and HIPC Initiative, due to their dogged insistence to make debt relief conditional on IMF conditionalities, do infringe a debtor country's right to an independent development process.

At least in theory, the IMF itself admits that a development process should be 'country-owned' which imply that the formulation of economic policies must be left in the hands of national authorities. The rhetoric, however, does not correspond to actual practice where the IMF actually approves or rejects PRSPs being submitted by debtor states. (Note 30) The final form, contents and duration of PRSPs must have the imprimatur of the IMF, otherwise the same will be rejected or sent back to the debtor country to incorporate the IMF's positions. In reality, the IMF does have a substantial role in determining the contents of these documents. This is because PRSPs are subject to a review and final approval by the IMF to ensure that its 'expectations' regarding the so-called 'four pillars of priority public actions' (which in reality are categories of conditionalities) are met. (Note 31) These pillars pertain to a country's (1) macroeconomic framework, (2) structural and sectoral policies, (3) policies for social inclusion and equity, and (4) governance and public sector management. It must be noted that these pillars do encompass almost the entire gamut of economic policy-making, such that it is hard to imagine what government policy relating to economic development is not included in this list of mandatory contents. Angela Wood aptly describes the IMF's attitude in the preparation of program documents purportedly 'owned' by debtor countries (Wood, 2005, p. 70):

However, governments often have little choice but to agree to an IMF program and the IMF is by no means a passive advisor. Indeed, the IMF regards itself as an enforcer of policy change. [A past evaluation of an IMF lending program] heard from developing country officials that the IMF had an 'inflexible attitude' and that the IMF often 'came to negotiations with fixed positions so that agreement was usually only possible through compromises in which the country negotiating teams moved to the Fund's positions.

Several authors have analysed the dynamics of the relationship between debtor countries and the IMF and have arrived at the similar conclusion that the IMF has real and effective power to shape economic policies in these countries. According to Gerry Helleiner, the IMF has 'a major effect upon the design of macroeconomic policy in the poorest countries' through the application of its conditionalities and the leverage it has over debt relief (Helleiner, 2000, pp. 90-91). William Canak and Danilo Levi agree with this finding and lament the fact that the IMF is 'fashioning the economic policies for the debtor nation, including decisions that have powerful effects on domestic conditions' (Canak and Levi, 1989, p. 155). According to them, this situation creates a 'maximum amount of uncertainty for debtor nations and a maximum amount of flexibility and control for creditors' (Canak and Levi, 1989, p. 155).

Still, other authors maintain that the IMF's dealings with debtor countries amount to much more than 'pressuring' or 'exerting influence', but they in fact border on outright 'coercion' or 'imposition'. Angela Wood explains that the Fund employs its supposed superior 'technical know-how' in order to 'impose policies on weaker governments against their wishes and often those of their citizens too' (Wood, 2005, pp. 67-68). Sharing this view, Martin Feldstein cautions creditor countries and the IMF not to take advantage of 'currency crises as an opportunity to force fundamental structural reforms on countries, however useful they may be in the long term' (Feldstein, 1998, pp. 20-33) In the same vein, Ariel Buira characterises IMF conditionalities as 'coercive' under certain situations (Buira, 2003, p. 60):

Conditionality can be said to be coercive when the cost of not accepting the conditionality is so high that a country has no choice but to accept conditions that make it do things it would not otherwise, particularly as countries have a strong preference for avoiding the costs of default.

Whether debtor countries will be pressured or coerced to accept conditionalities ultimately depends, therefore, if they have alternative sources of finance to pay their public debts. If debtor countries can find alternative sources, like borrowing from private commercial banks or expanding their revenue base by tax increases or austerity measures, the pressure on them to accept conditionalities will be significantly less. On the other hand, if debtor countries do not have these options, the pressure on them to swallow unpalatable conditions will be heavier. It will be recalled that debtor countries that seek relief through the Paris Club and the HIPC Initiative are countries that have already defaulted on their debt service payments or are teetering at the brink of default. Therefore, obtaining finance from private commercial lenders will depend on whether the latter are willing to put their trust, and thus risk their money, on low-income countries' future ability to pay. While it is not totally impossible, it is highly unlikely without them getting the 'seal of approval' from the IMF. HIPC-eligible countries, it will be recalled, are eligible for highly concessional lending precisely because they lack access to private finance. For the 41 countries currently undergoing the HIPC Initiative, raising taxes or tightening their belts are unrealistic options because most, if not all of them, already have low levels of expenditures for basic social services. To paraphrase Jeffrey Sachs, how can belt-tightening be an option when these people cannot even afford to buy belts (Sachs, 2005, pp. 342-3)? 
It is appropriate to discuss here the IMF's response to the recent global financial crisis which has spread from developed to developing countries in early 2009. Has the crisis caused the IMF to modify its lending policies as well as the conditionalities attached to loans? The answer is 'yes' and 'no'. First, in order to cushion the impact of the financial crisis to low-income countries, the IMF has announced the availability of 'significant new resources underpinned by new lending instruments' (IMF, 2009, p. 1). This means that there will be increased levels of concessional lending to 'eligible and qualified' low-income countries as determined by the Fund. Second, however, the global financial crisis has not affected the IMF's policy on requiring conditionalities on both loans and debt relief. This is because the new lending instruments do not deviate at all from the need to attach conditionalities. In other words, new funds became available to lend to low-income countries but the same old conditionalities are required of them. The announcement that the new lending instruments will require 'streamlined' conditionality (IMF, 2009, p. 1) should be taken with a grain of salt. The IMF has been assuring, and reassuring, debtor countries of 'streamlined' conditionalities for years, but the actual contents of decision-point documents, PRSPs and other debtor country documents paint a picture of a supranational institution dictating on debtor countries what they should and should not do.

Do conditionalities violate a debtor country's permanent sovereignty over its natural wealth and resources? When foreign control or influence inhibits a people from possessing, using or disposing of their natural wealth and resources as they deem proper, this particular specie of sovereignty is violated. Conditionalities that require the privatisation of primary export products (like coffee, cotton and copper) and energy sources (like natural gas, geothermal and hydroelectricity) are not easy to reconcile with the people's permanent sovereignty over natural wealth and resources. Natural resources like these are part of a debtor country's national patrimony that only it has the sovereign right to allocate, use or permit another to do so.

Although it is difficult to say with certainty, IMF policy prescriptions may in fact work and be beneficial to a debtor country in the long term. For example, trade liberalisation might indeed create more competition, lower the prices of commodities and encourage efficiency as is often claimed. But that is not the issue here. The problem arises when these policies are required of debtor countries as a condition for debt relief, because then the right of a people to pursue a process of development independently and free from intrusions is compromised. According to Martin Feldstein, 'the legitimate political institutions of the country should determine the nation's economic structure and the nature of its institutions' (Feldstein, 1998, pp. 20-33). Along the same line, Ariel Buira argues that the desperate financial and economic situation a country finds itself in 'does not give the IMF the moral right to substitute its technical judgments for the outcome of the nation's political process' (Buira, 2003, p. 57) Sabine Michalowski equates this trampling of the political process of debtor nations as 'a factual loss of sovereignty over their economic and social policies' (Michalowski, 2008, pp. 35-37). This was precisely the fear of some members of the British Parliament when they were presented the blueprint of the planned international credit union (which would eventually become the IMF) in the early 1940s - that IMF programs 'would entail policy conditions that would impinge upon national sovereignty' of member states (Vreeland, 2007, pp. 21-22). They were assured by John Maynard Keynes, who developed the British proposal for such credit union and who was considered the greatest economist of his time, that the future IMF would only offer limited policy 'advice' to governments and their economic and social policies would be 'immune from criticism by the fund' (Vreeland, 2007, pp. 21-22). History would later prove Keynes utterly wrong on this point.

The Paris Club and the HIPC Initiative are powerful and coercive instruments of the major creditor countries. Through these debt relief mechanisms, creditor countries are pushing their own economic paradigm to the poorest of debtor countries who are pressured, or rather coerced, to submission. In the Paris Club and HIPC Initiative renegotiations, creditors and debtors stand on highly unequal footing such that 'agreements' reached are not really meetings of the mind but coercions masquerading as covenants. The decision to undertake any economic or social policy must come from the debtor country itself, and not as a result of a policy imposition by an external and non-accountable institution.

\section{Conclusion}

The rules of international law play a less significant role in the Paris Club and HIPC Initiative as both rely exclusively on debtor countries' compliance with conditionalities to set their processes in motion. Conditionalities are often viewed as belonging to the exclusive realm of economics and have rarely been scrutinised under the lens of general international law. Considerations of, inter alia, respect for debtor states' economic self-determination, their sovereignty over natural resources, human and people's rights, or the requirements of effective international cooperation are noticeably absent in both mechanisms. While the Paris Club and HIPC Initiative are not proceedings before courts or quasi-judicial bodies, there is no cogent reason why the long arm of international law cannot reach both. Indeed, there is no reason why any actor in the international arena for that matter (especially the creditor states and the IMF) is exempt from general international law. Established and managed by states, the Paris Club process and HIPC Initiative are not immune from the demands of international law and, in particular, of the right to economic self-determination.

One is therefore tempted to ask - are the Paris Club and HIPC Initiative respectful of the 'rule of law' in the international system? Ross P. Buckley argues that the 'rule of law' is present in any system, whether domestic or 
international, when a significant majority of the actors in that system do comply with an established set of laws which is seen as legitimate and enjoying a broad measure of community support (Buckley, 2005, p. 141). The Paris Club of creditor countries and the HIPC Initiative are undoubtedly international institutions exercising significant power and authority in the field of sovereign debt workouts. Their actions and decisions have far reaching ramifications in the lives of people in debtor countries. However, referring specifically to the principle of impartiality as a facet of the rule of law, Kunibert Raffer laments that (Note 32):

Present sovereign debt management does not honour the very foundation of the Rule of Law that one must not be judge in one's own cause, and change is not in sight. Creditors have been judge, jury, expert, bailiff, even the debtor's lawyer all in one, which mocks the very foundation of the Rule of Law.

The Paris Club and the HIPC Initiative are actors in their own right in the international system that ought to observe and comply with the rules of international society. Economic self-determination, sovereignty over natural resources, human and people's rights, and effective international cooperation, inter alia, are well-established rules of international law. These rules ought to be observed in both debt relief mechanisms because the international rule of law demands it. Spencer Zifcak argues that all institutions operating in the international arena are not immune from these rules (Zifcak, 2005, p. 52):

If the rule of law is genuinely to be globalized, it cannot be permissible for certain institutions of international governance to ignore or downgrade critical principles and values that underpin it. Instead, these values and principles must be incorporated into every aspect of their work.

Creditor states, when they create institutions like the Paris Club and the HIPC Initiative or participate in them, cannot divest themselves of the international duties or obligations they have assumed expressly by treaty law and impliedly by customary international law (e.g. customs and jus cogens). The Paris Club and HIPC Initiative do not provide creditor states a cloak of immunity from the general operation of international law rules. Both inside and outside these institutions, creditor states carry those duties or obligations and remain duty-bound to observe them.

\section{References}

Babb, S. \& Buira, A. (2005). Mission Creep, Mission Push and Discretion: The Case of IMF Conditionality. In A. Buira (ed.), The IMF and the World Bank at Sixty. London: Wimbledon Publishing Company.

Barcelona Traction Case, (Belgium v. Spain), International Court of Justice, para. 72, Judgment of 5 February 1970.

Bedjaoui, M. (1991). The Right to Development. In M. Bedjaoui (ed.), International Law: Achievements and Prospects. Martinus Nijhoff Publishers.

Bird, G. (2001). IMF Programmes: Is There a Conditionality Laffer Curve? World Economics 2, 29-49.

Buckley, R. (2005). The Role of the Rule of Law in the Regulation of Global Capital Flows. In S. Zifcak (ed.), Globalisation and the Rule of Law. New York: Routledge.

Buira, A. (2003). An Analysis of IMF Conditionality. In A. Buira (ed.), Challenges to the World Bank and IMF: Developing Country Perspectives. London: Wimbledon Publishing Company.

Canak, W. \& Levi, D. (1989). Social Costs of Adjustment in Latin America. In J. Weeks (ed.), Debt Disaster? Banks, Governments, and Multilaterals Confront the Crisis. New York: New York University Press.

Cassese, A. (1986). International Law in a Divided World. Oxford University Press.

Crawford, J. (1988). The Rights of Peoples: Peoples or Governments? In J. Crawford (ed.), The Rights of Peoples. Oxford: Clarendon Press.

Dicke, D. (1988). The Concept of Coercion: A Wrong in Itself. In P. de Waart, P. Peters \& E. Denters (eds.), International Law and Development. Martinus Nijhoff Publishers.

Feldstein, M. (1998). Refocusing the IMF. Foreign Affairs 77(2), 20-33.

Head, J. (2005). The Future of the Global Economic Organizations: An Evaluation of Criticisms Leveled at the

$I M F$, the Multilateral Development Banks, and the WTO. New York: Transnational Publishers, Inc.

Helleiner, G. (2000). External Conditionality, Local Ownership and Development. In J. Freedman (ed.), Transforming Development: Foreign Aid for a Changing World. Toronto: University of Toronto Press.

Hopkinson, N. (1989). The Evolving World Debt Problem (Wilton Park Papers, Conference Report 2-6 May 1989) 13.

International Monetary Fund and the World Bank (2001), Debt Relief for Poverty Reduction: The Role of the Enhanced HIPC Initiative.

International Monetary Fund, The IMF's Response to the Global Crisis: Meeting the Needs of Low-income Countries (29 July 2009). [Online] Available: http://www.imf.org/external/np/lic/2009/072909.htm (30 September 2009. 
International Law Commission, Yearbook of the ILC, 1988, vol. II, Part 2, p. 64.

Killick, T. (1995). Can the IMF Help Low-Income Countries? Experiences with Its Structural Adjustment Facilities. The World Economy 18, 603-16.

Korner, P., Maas, G., Siebold, T. \& Tetzlaff, R. (1986). The IMF and the Debt Crisis (1986). London: Zed Books.

Meessen, K. (1986). IMF Conditionality and State Sovereignty. In Detlev Chr. Dicke (ed.), Foreign Debts in the Present and a New International Economic Order. Friebourg, Switzerland: University Press.

Michalowski, S. (2008). Sovereign Debt and Social Rights - Legal Reflections on a Difficult Relationship. Human Rights Law Review 8(1), 35, 37.

Rieffel, L. (2003). Restructuring Sovereign Debt. Washington, DC: The Brookings Institution.

Rustomjee, C. (2005). Improving Southern Voice on the IMF Board: Quo Vadis Shareholders? In B. Carin \& A. Wood (eds.), Accountability of the International Monetary Fund. Burlington, VT (USA): Ashgate Publishing Company.

Sachs, J. (2005). The End of Poverty: Economic Possibilities for Our Time. New York: Penguin Press.

Seiber, M. (1982). International Borrowing by Developing Countries. New York: Pergamon Press.

Schachter, O. (1976). The Evolving International Law of Development. Columbia Journal of Transnational Law 15, 1, 14.

Shaw, M. (2008). International Law. Cambridge University Press.

Simma, B. (2002). The Charter of the United Nations: A Commentary. Oxford University Press.

Sturzenegger, F. \& Zettelmeyer, J. (2006). Debt Defaults and Lessons from a Decade of Crises. Cambridge, MA: MIT Press.

Tiewul, S. A. (1975). The UN Charter of Economic Right and Duties of States. Journal of International Law and Economics 10, 645, 670.

Toussaint, E. (1998). The Tyranny of Global Finance. London: Pluto Press.

Vreeland, J. R. (2007). The International Monetary Fund: Politics of Conditional Lending. London and New York: Routledge.

Wood, A. (2005). Power Without Responsibility? Enhancing Learning and Policy Accountability at the IMF. Iin B. Carin \& A. Wood (eds.), Accountability of the International Monetary Fund. Burlington, VT (USA): Ashgate Publishing Company.

Woods, N. (2006). The Globalizers: The IMF, the World Bank and Their Borrowers. New York: Cornell University Press.

Zifcak, S. (2005). Globalizing the Rule of Law: Rethinking Values and Reforming Institutions. In S. Zifcak (ed.), Globalisation and the Rule of Law. New York: Routledge.

Notes

Note 1. The World Bank (2003), Debt Relief for the Poorest: An OED Review of the HIPC Initiative, 8.

Note 2. World Bank and International Monetary Fund, Heavily Indebted Poor Countries (HIPC) Initiative and Multilateral Debt Relief Initiative (MDRI) Status of Implementation (2006) [Online] Available: www.imf.org/external/np/pp/eng/2006/082106.pdf (25 August 2008).

Note 3. Paris Club, Permanent Members and Other Official Creditors (2009) [Online] Available: http://www.clubdeparis.org/sections/qui-sommes-nous/membres-permanents-et (25 April 2009).

Note 4. Paris Club, Description of the Paris Club (2009) [Online] Available: http://www.clubdeparis.org/sections/qui-sommes-nous (25 April 2009).

Note 5. Paris Club, Negotiation Sessions (2009) [Online] Available: http://www.clubdeparis.org/sections/que-faisons-nous/sessions-de-negociation (26 April 2009).

Note 6. Hahn, H. (1986). The Restructuring of International Debt: Recent Developments. In Detlev Chr. Dicke (ed.), Foreign Debts in the Present and a New International Economic Order (pp. 97, 98-99). Friebourg, Switzerland: University Press.

Note 7. Paris Club, Principles of the Paris Club (2009) [Online] Available: http://www.clubdeparis.org/sections/principes-et-regles/principes (25 April 2009).

Note 8. The IMF, Debt Relief under the HIPC Initiative (2009) [Online] Available: http://www.imf.org/external/np/exr/facts/hipc.htm (26 April 2009). 
Note 9. The IDA is the part of the World Bank Group that lends on highly concessional terms. Concessional lending is available for low-income countries only, with the eligibility criteria based on a country's per capita income and lack of access to private finance. See, eg, Mohammed, A. (2005). Who Pays for the World Bank? In A. Buira (ed.), The IMF and the World Bank at Sixty (pp. 181, 187). London: Wimbledon Publishing Company.

Note 10. The World Bank, Steps of the HIPC Initiative (2009) [Online] Available: http://go.worldbank.org/76G2TJJO30 (15 May 2009).

Note 11. The World Bank, Steps of the HIPC Initiative (2009) [Online] Available: http://go.worldbank.org/76G2TJJO30 (15 May 2009).

Note 12. The World Bank, HIPC at a glance guide (Spring 2009) [Online] Available: www.worldbank.org/economicpolicyanddebt (15 May 2009).

Note 13. The World Bank, Steps of the HIPC Initiative (2009) [Online] Available: http://go.worldbank.org/76G2TJJO30 (15 May 2009).

Note 14. The IMF, Poverty Reduction Strategy Papers (PRSPs): A Fact Sheet (2008) [Online] Available: http://www.imf.org/external/np/exr/facts/prsp.htm (9 October 2008).

Note 15. The World Bank, Steps of the HIPC Initiative (2009) [Online] Available: http://go.worldbank.org/76G2TJJO30 (15 May 2009).

Note 16. The World Bank, Steps of the HIPC Initiative (2009) [Online] Available: http://go.worldbank.org/76G2TJJO30 (15 May 2009).

Note 17. The IMF, Debt Relief under the HIPC Initiative (2009) [Online] Available: http://www.imf.org/external/np/exr/facts/hipc.htm (15 April 2009).

Note 18. The IMF, Debt Relief under the HIPC Initiative (2009) [Online] Available: http://www.imf.org/external/np/exr/facts/hipc.htm (15 April 2009).

Note 19. The World Bank, HIPC at a glance guide (Spring 2009) [Online] Available: www.worldbank.org/economicpolicyanddebt (15 May 2009).

Note 20. Independent Evaluation Office of the IMF, Evaluation of Structural Conditionality in IMF-Supported Programs (2009), Background Document I, para 2, [Online] Available: http://www.ieo-imf.org/eval/complete/eval_01032008.html (15 May 2009).

Note 21. Independent Evaluation Office of the IMF, Evaluation of Structural Conditionality in IMF-Supported Programs (2009), Background Document I, para 2, [Online] Available: http://www.ieo-imf.org/eval/complete/eval_01032008.html (15 May 2009).

Note 22. See, eg, Vreeland, J.R. (2007). The International Monetary Fund: Politics of Conditional Lending (pp. 23-25). London and New York: Routledge; King, R. \& Robinson, M. (1989). Assessing Structural Adjustment Programs: A Summary of Country Experience. In J. Weeks (ed.), Debt Disaster?Banks, Governments, Multilaterals Confront the Crisis (p. 103). New York: New York University Press.

Note 23. Sachs, J. (2005). The End of Poverty: Economic Possibilities for Our Time (pp. 81-82, 280-81, 342). New York: Penguin Press; Dent, M. \& Peters, B. (1999). The Crisis of Poverty and Debt in the Third World (pp. 73-79). Brookfield, VT: Ashgate; Toussaint, E. (1999). The Tyranny of Global Finance (pp. 155-65). London: Pluto Press.

Note 24. Buira, A. (2003). An Analysis of IMF Conditionality. In Ariel Buira (ed.), Challenges to the World Bank and IMF: Developing Country Perspectives (pp. 55, 61). London: Wimbledon Publishing Company.

Note 25. Hardstaff, P. (2003). Treacherous Conditions: How IMF and World Bank policies tied to debt relief are undermining development, World Development Movement, [Online] Available: www.wdm.org.uk (2 May 2009).

Note 26. On the influence of creditor countries on the decisions of the IMF, see, eg, Feldstein, M. (1998). Refocusing the IMF. Foreign Affairs 77(2), 20-33; Millet, D. \& Toussaint, E. (2004). Who Owes Who? 50 Questions About World $\operatorname{Debt}$ (p. 41). London: Zed Books.

Note 27. The Vienna Convention on the Law of Treaties requires no less than coercion on the person of the representative of the state (article 51) or coercion of a state by threat or use of force (article 52) to invalidate a treaty or international agreement. See, eg, Reuter, P. (1989). Introduction to the Law of Treaties (pp. 139-43). London and New York: Pinter Publishers.

Note 28. Parliament of the Commonwealth of Australia, Report of the Joint Standing Committee on Foreign Affairs, Defence and Trade, World Debt: A report on the proceedings of a seminar, 27 August 1999, 37-42. 
Note 29. The Australian Macquarie Dictionary defines the word 'incentive' as ' 1 . something that influences (someone) to act, adj. 2. influencing, as to action; stimulating; provocative.'

Note 30. Levinsohn, J. (2003). The Poverty Reduction Strategy Paper Approach: Good Marketing or Good Policy? In A. Buira (ed.), Challenges to the World Bank and IMF: Developing Country Perspectives (pp. 119, 123). London: Wimbledon Publishing Company.

Note 31. Independent Evaluation Office of the IMF, Evaluation of the IMF's Role in Poverty Reduction Strategy Papers and the Poverty Reduction and Growth Facility (2004) 16-17.

Note 32. Raffer, K. Comment on the Report of the UN Secretary-General: In larger freedom: towards development, security and human rights for all, p 1., [Online] Available: www.un-ngls.org/orf/UNreform/UniversityofVienna.doc (21 July 2009).

Table 1. List of Heavily Indebted Poor Countries (HIPCs) As of end-March 2009, The IMF

\begin{tabular}{|l|l|l|}
\hline \multicolumn{3}{|c|}{ 25 Completion Point Countries } \\
\hline Benin & Guyana & Niger \\
\hline Bolivia & Honduras & Rwanda \\
\hline Burkina Faso & Madagascar & Sao Tome \& Principe \\
\hline Burundi & Malawi & Senegal \\
\hline Cameroon & Mali & Sierra Leone \\
\hline Ethiopia & Mauritania & Tanzania \\
\hline Gambia & Mozambique & Uganda \\
\hline Ghana & Nicaragua & Zambia \\
\hline \multicolumn{3}{|l|}{ Decision Point Countries } \\
\hline Afghanistan & Congo, Rep. of & Haiti \\
\hline Central African Rep. & Cote d'Ivoire & Liberia \\
\hline Chad & Guinea & Togo \\
\hline Congo, D. Rep. of & Guinea-Bissau \\
\hline \multicolumn{3}{|l|}{ 5 Pre-Decision Point } \\
\hline Comoros & Kyrgyz Rep. & Sudan \\
\hline Eritrea & Somalia & \\
\hline
\end{tabular}


Table 2. Major Groupings of IMF Conditionalities in the Paris Club process and HIPC Initiative

\begin{tabular}{|c|c|}
\hline Conditionalities & $\begin{array}{l}\text { Specific examples actually } \\
\text { required of HIPCs }\end{array}$ \\
\hline Trade liberalisation & $\begin{array}{l}\text { - Non-protection of infant industries } \\
\text { - Elimination or reduction of tariffs or } \\
\text { import quotas } \\
\text { - Promotion of exports }\end{array}$ \\
\hline Government austerity measures & $\begin{array}{l}\text { - Reduction of salary of public sector } \\
\text { employees } \\
\text { - Removal of agricultural subsidies } \\
\text { - Level of spending on education and } \\
\text { health } \\
\text { - Charging 'user fees' for education } \\
\text { and health services }\end{array}$ \\
\hline Privatisation of state-owned enterprises & $\begin{array}{ll}\text { - } & \text { Water utilities } \\
\text { - } & \text { Electricity generation and distribution } \\
\text { - } & \text { Telecommunications } \\
\text { - } & \text { Infrastructure } \\
\text { - } & \text { Primary export product like coffee or } \\
& \text { groundnut }\end{array}$ \\
\hline Taxation reforms & $\begin{array}{ll}\text { - } & \text { Introduction of the value-added tax or } \\
\text { other regressive taxes } \\
\text { - } & \text { Changes in tax rates of corporations } \\
\text { - } & \text { Tax holidays for foreign corporations } \\
\text { - } & \text { Improvement of customs collection } \\
\end{array}$ \\
\hline Fiscal and monetary reforms & $\begin{array}{ll}\text { - } & \text { Strict inflation targeting } \\
\text { - } & \text { Accumulation of international } \\
& \text { reserves } \\
\text { - } & \text { Expansion of domestic credits } \\
\text { - } & \text { Devaluation } \\
\end{array}$ \\
\hline Regulatory reforms & $\begin{array}{ll}\text { - } & \text { Regulation of banks } \\
\text { - } & \text { Strengthening regulation of financial } \\
\text { - } & \text { Sector } \\
\text { - } & \text { investors } \\
\text { - Changes in laws governing land } \\
\text { ownership of foreigners }\end{array}$ \\
\hline Reforms in the civil service (bureaucracy) & $\begin{array}{ll}\text { - } & \text { Anti-corruption legislation } \\
\text { - } & \text { Improving public procurement }\end{array}$ \\
\hline Others & $\begin{array}{ll}\text { - } & \text { Prevention of money-laundering } \\
\text { - } & \text { Prevention of terrorist financing } \\
\text { - } & \text { Introduce energy conservation } \\
& \text { measures } \\
\text { - } & \text { Develop indigenous energy sources } \\
\end{array}$ \\
\hline
\end{tabular}

